\title{
The Dominance of Pyramidal Busi- ness Groups in Latin America Persists
}

\author{
Susan Perkins, University of Illinois at Chicago, USA
}

Latin American capital market integration took place in 2011, combining the national stock exchanges of Colombia, Chile, Peru, and most recently, the addition of Mexico in 2014. These four stock exchanges combined, known as the Mercado Integrado Latinoamericano (MILA), represent the largest regional stock exchange in Latin America and it is a close second in size (e.g., market capitalization) to the BOVESPA in Brazil, the single largest national stock exchange in Latin America. ${ }^{1}$ Since the integration, what many practitioners and scholars of corporate governance are asking: Is the MILA ready for "good governance" rules?

\section{Business Groups in Latin America}

The corporate governance context in Latin America deviates significantly from the one-vote, one-share proportional representation of the concentric overlap between ownership and voting rights found most commonly in the US. Many who understand and practice corporate governance in the context of the US or UK undoubtedly are most familiar with dispersedly owned stand-alone firms that rarely have any other affiliated firms also listed on the same stock exchanges. The key governance concern when considering these dispersedly owned firms found on the New York or London stock exchanges is the "principal-agent dilemma" that can arise within the boundaries of the firm between the separation of ownership (the principals) and managerial control (agents) (Jensen \& Meckling, 1976). At the worst when the two are not properly aligned, scandalous managers can obfuscate their fiduciary responsibilities to instead maximize their personal wealth at the expense of appropriations to the shareholders, the rightful owners. However, in contrast, business groups - also known as grupos in Latin America -- often have a dominant shareholder who also plays a significant role in firm management, thus creating a different set of corporate governance concerns, such as the likely goal divergence and information asymmetry between the dominant owner-manager(s) (in this scenario, the principal-agent role is combined) and minority shareholders, whom are frequently foreign investors. International business scholars, in both management and finance, have long been intrigued by this highly diversified and socially embedded organizational form. The seminal study by La Porta et al. (1998) on global corporate governance and ownership revealed a ubiquitous pattern of more concentrated ownership around the world which suggests that the ownership forms we observe in Latin America are more common, in fact, than rare. Many Latin American countries are characterized by having extremely high ownership concentrations with yet some of the poorest levels of investor protections. One of the largest corporate governance issues in Latin America ${ }^{2}$ called out in this study is the disproportional representation of a small set of controlling owners which often leads to elevated expropriation risks (see Table 1). Since this study was published over two decades ago, two important questions that practitioners face when devising corporate governance and ownership structures in this region are: Do these concentrated ownership forms persist given the institutional reforms designed to curb such governance problems related to managerial entrenchment? and Do these ownership forms pose a threat to potential joint venture partners or minority shareholders given the revelations of more recent Latin American corporate governance research which exposed potential expropriation schemes of local pyramidal group partners (Perkins, Morck \& Yeung, 2013) and competing market forces from new varieties of state-controlled capitalism (Musacchio \& Lazzarini, 2013)?

Descriptive statistics comparing the patterns of corporate ownership in Latin America over the last decade show no major shifts in ownership patterns of the concentrated dominant owners. Figures 1 and 2 provide some stylized facts that on several Latin American stock exchanges - including the Santiago Stock Exchange, Chile (BCS); Mexican Bolsa, Mexbol (BMV); Colombia Stock Exchange (BVC); Lima Stock Exchange, Peru 
(BVL); Bolsa de Valores de São Paulo, Brazil (BOVESPA) -- the level of dominant ownership of the single largest shareholder and the top 5 largest shareholders' average ownership persisted over the last decade when comparing ownership in 2007 to 2017. The top shareholders maintained both voting and decision rights based on their majority/controlling stakes in the firm. These patterns of ownership throughout Latin American contrast from the more dispersedly owner listed firms in the UK and US (Figure 3) where the largest shareholder, on average, owns less than $16 \%$ stakes.

Table 1. Corporate Ownership and Expropriation Risks in Latin America

\begin{tabular}{lcc} 
& Risk of Expropriation & $\begin{array}{c}\text { Ownership \% } \\
\text { - Largest 3 } \\
\text { Shareholders }\end{array}$ \\
Country & Index $[\mathbf{0 - 1 0 ;}$ =-High] & \\
\hline Argentina & 5.91 & $53 \%$ \\
Brazil & 7.62 & $57 \%$ \\
Chile & 7.5 & $45 \%$ \\
Colombia & 6.95 & $63 \%$ \\
Ecuador & 6.57 & \\
Mexico & 7.29 & $64 \%$ \\
Peru & 5.54 & $56 \%$ \\
Uruguay & 6.58 & $51 \%$ \\
Venezuela & 6.89 & $19 \%$ \\
\hline \multicolumn{1}{c}{ Widely-held Stand Alone Country Benchmarks } \\
\hline UK & 9.71 & $20 \%$ \\
US & 9.98 & \\
\hline
\end{tabular}

Source: Data extracted from LaPorta, Lopez-de-Silanes, Shleifer, \& Vishny (1998).

One key point of contestation of these business groups, relative to other corporate governance forms, is the corporate governance mechanisms that leave minority shareholders prey to the self-dealing behaviors of the dominant owner or most notably referred to as the "private benefits of control." The idea of self-dealing, different than the classic principal-agent dilemma, refers to the act of the controlling owner's misuse of their power over the managerial decision rights to divert the wealth of the firm for personal gains. Djankov, La Porta, Lopez-de-Silanes and Shleifer's (2008) global study on self-dealing, which provided comparative analysis across 72 countries, showed that Latin American countries rank the highest among other regions for expropriation risks of self-dealing by the dominant controlling shareholders. Of these country-level comparisons, Brazil and Mexico had the highest control premiums of all, at $49 \%$ and $47 \%$ respectively. Venezuela was also among the top 5 ranked highest for control premiums. ${ }^{3}$ To confound the
Figure 1

Latin American Stock Exchanges Ownership Concentration 2017

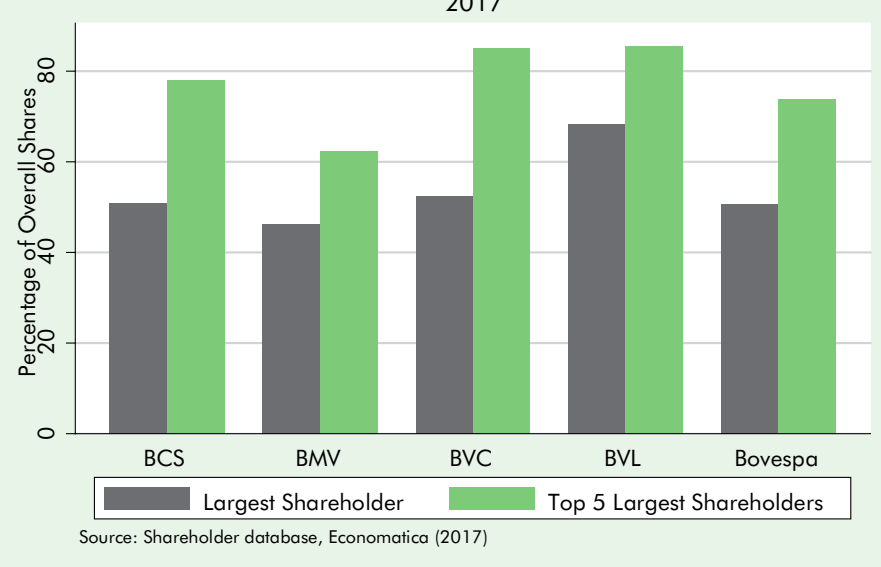

Figure 2

Latin American Stock Exchanges Ownership Concentration 2008

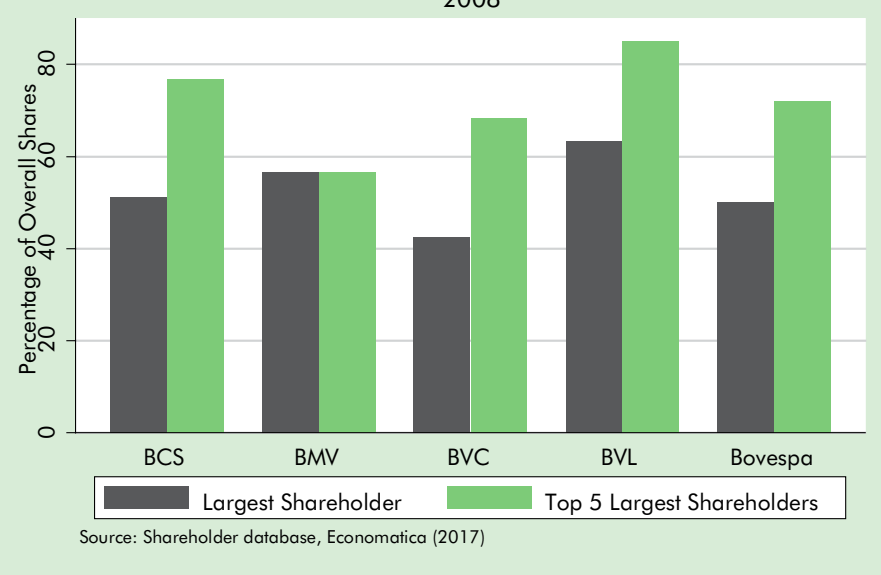

Figure 3

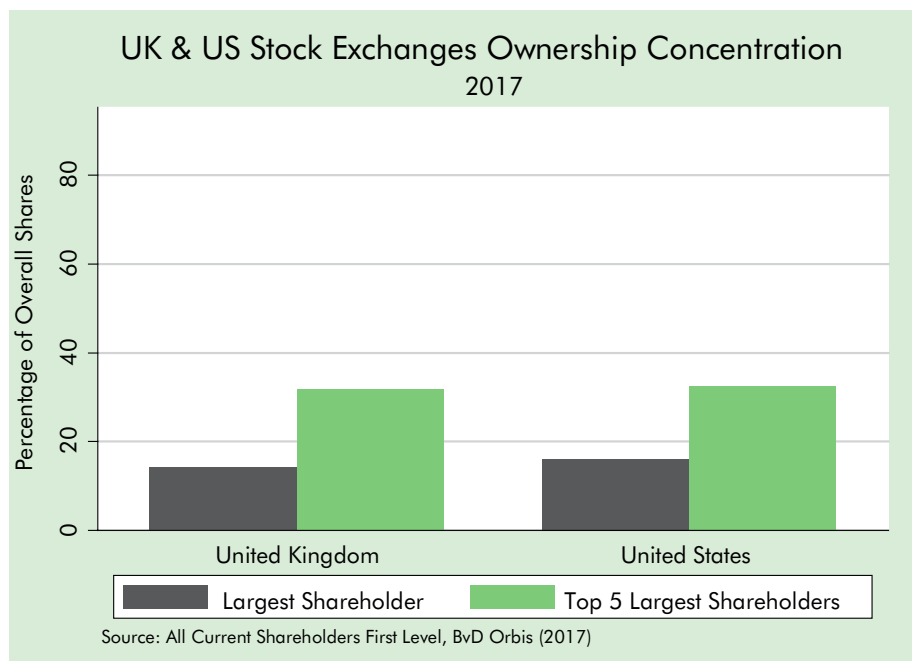


problem even further, Latin American countries also suffer from corporate governance challenges driven by an institutional context that provided very low anti self-dealing protections. In their anti-self-dealing index, Latin American countries represent 6 of the top $10^{4}$ for the lack of shareholder protections in the law to curb such behaviors.

Also vastly different than the US and UK capital markets, some public firms in Latin America have dual-class shares both with and without voting rights. The agency problems are even further exacerbated when the dominant owner exerts distorted levels of control through dual class voting shares and other control mechanisms that create paths to maximize the wealth of the pyramidal group's apex rather than the lower-tiered publicly listed firms. The high agency costs to minority shareholders locked out from control stems from the large gap between control and cash flow rights that then gives the controlling owner(s) the ability to leverage their stakes across tiers of the pyramidal corporate structure of which many are not transparent to the market. A cross-country comparative study (Nenova, 2003) that focuses on dual-class shares and control blocks found that among the 18 countries examined, Brazil had the highest use of dual class shares. In Brazilian listed firms, for example, ordinary shares $(\mathrm{ON})$ are the only class of shares that carry voting rights and are predominately owned by the controlling shareholder(s). Preferred shares (PN), mostly owned by minority shareholders and foreigners, carry no voting rights. This cross-country comparative study further revealed that the control block ownership of publically listed firms in Latin American countries including Brazil, Chile and Mexico represented more than a quarter of the companies' market capitalization. Indeed, others, such as Dyck and Zingales (2004), have pinpointed the premiums associated with these control blocks of the dominant shareholders as being unusually high in Brazil, the highest at $65 \%$ relative to control premiums in 38 other capital markets studied around the world; 34\% in Mexico; 27\% in Argentina and Venezuela; $18 \%$ in Chile; and $14 \%$ in Peru, compared to $1 \%$ in both the US and UK. The primary motives of such ownership combined with dominance of the decisions rights points back to increased opportunities for self-dealing. The biggest problem identified with corporate structures that have concentrated control is the risk of expropriation from the controlling owner to give preferential treatment to their own. Expropriation risks are higher because the main shareholder, which is often a dominant owner of a powerful business group, could effectively govern and determine the strategic decisions of the firm with limited to no rights given to minority shareholders. For this reason, management scholars of Latin American corporate governance have referred to pyramidal groups as either "paragons" or rent-seeking "parasites" (Khanna \& Yafeh, 2007) because of the difficulty in detecting the true wealth maximization motives either directed towards the wealth maximization of the firm or self-dealing motives to maximize the wealth of the dominant/controlling shareholder(s). From this perspective, the presence of a share- holder with large equity holdings is indicative of costs to other shareholders, based on the presumption that ownership control will result in value going disproportionately to the ultimate main shareholder at the expense of others.

The sum of these insights revealed from cross-country comparative views of corporate governance practices in Latin America may bring hesitations regarding market investments to the unassuming manager, particularly those accustomed to more Anglo-American governance norms (e.g., one vote, one share norms). Most importantly, however, these insights underscore the importance of both the corporate governance practices of firms within a given institutional context and the financial markets upon which these firms rely. Therefore, the underlying concerns that are most important to consider are not solely whether there is a dominant controlling owner, but what are the prevailing corporate governance practices being utilized by the firm?

\section{Brazilian Securities Regulators Changed the "Rules of the Game"}

This inability of the market to not easily detect the wealth maximization motives of many listed dominantly owned firms became a severe problem for the liquidity of the BOVESPA in Brazil by the end of 1999. As economic theory predicts, markets without these fundamental minority shareholder protections will receive less overall investments and fewer firms will be inclined to go public. The reality of the BOVESPA nearly collapsing made evident to the Brazilian government by 2000 that corporate governance institutional reforms were needed to address this market failure. Why might Brazil be a model for the MILA exchange or others countries that have dominant shareholders and lack strong minority shareholder protections? Because in 2001, the Brazilian securities and exchange commission, Comissão de Valores Mobiliários (CVM), reformed the "rules of the game" on the BOVESPA with the hope of providing more mechanisms of "good governance" practices such as greater transparency, disclosure rules requiring using US Generally Accepted Accounting Principles (GAAP) audited financials, instituting board requirements to adopt independent directors at a ratio of 1 to 5 per board seat, and limiting the disproportions between voting stakes shares versus non-voting shares. These are all considered exemplars of "good governance" practices commonly found in developed economies, but are relatively new to emerging markets (La Porta el al., 1998). The clever solution embedded into the institutional reform recognized that not all listed Brazilian firms had poor governance practices, but those that were better governed had no credible way to signal to the market their wealth maximization motives. The regulatory changes introduced three new voluntary corporate governance listing categories, including the Novo Mercado being the most stringent, followed by Level 2 then Level 1 cor- 
Figure 4

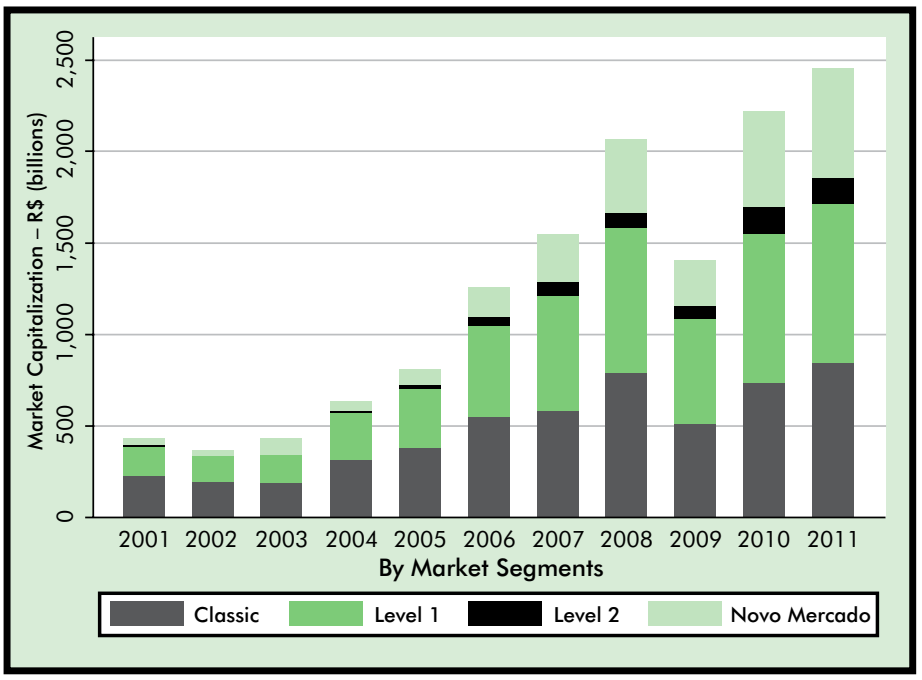

Source: Securities Financial Database, Economatica, 2017

porate governance listing segments, of which each has unique regulatory reporting and compliance requirements. This regulatory shift provided both existing (seasoned equity offerings, SEOs) and new equity offerings (initial public offerings, IPOs) listed on the BOVESPA a voluntary path towards increasingly more stringent governance rules to allow each firm to signal to the market their commitment to stronger shareholder rights reinforced by a redistribution of more proportional voting rights. The Brazilian corporate governance reforms also created a market arbitration chamber where shareholder disputes are settled within six months, a needed solution to counter the inefficient judicial systems where firms often experienced slowness in having a case heard and a lack of specialization around these governance issues.

Brazil's regulatory reforms to Latin America's largest stock market created a turnaround in the growth trajectory of a previously failing market which suffered from corporate governance institutional voids. From 2001-2011, the increasing market capitalization of the BOVESPA was primarily driven by the stocks in the more stringent listing categories, mainly the Novo Mercado and Level 1 (Figure 4). Perhaps these results reveal what is most needed in Latin America are regulatory interventions to improve the weak investor protections given that these dominantly owned business groups persist. Considering the effectiveness of regulatory strategies that Brazil has put in place in their capital markets over the last two decades to reform problems of "bad corporate governance practices" that often left minority shareholders getting the short end of the stick, this may be a winning strategy for other Latin American stock exchanges. Market regulators in Brazil already provided the test of the durability of this corporate ownership form.

The long-term strategy for Latin American markets perhaps is not to expect the dominant ownership structures to change, but instead to incentivize better corporate governance practices of these business groups. The policy regime in Brazil can be a useful benchmark for other emerging market economies looking for the next step in developing and/or stabilizing capital market growth.

\section{References}

Dyck A., \& Zingales, L. 2004. Private benefits of control: An international comparison. Journal of Finance, 59(2): 537-600.

La Porta, R., Lopez-de-Silanes, F., Shleifer, A. \& Vishny, R. W. 1998. Law and finance. Journal of Political Economy, 106(6): 1113-1155.

Jensen M., \& Meckling, W. 1976. Theory of the firm: Managerial behavior, agency costs and ownership structure. Journal of Financial Economics, 3(4): 305-360.

Khanna T., \& Yafeh, Y. 2007. Business groups in emerging markets: paragons or parasites? Journal of Economic Literature, 45(2): 331-372.

Mussachio, A., \& Lazzarini, S.G. 2013. Reinventing State Capitalism: Leviathan in Business, Brazil and Beyond. Boston: Harvard University Press.

Nenova, T. 2003. The value of corporate voting rights and control: A cross-country analysis. Journal of Financial Economics, 68: 325-351.

Perkins, S., Morck, R., \& Yeung, B. 2014. Innocents abroad: The hazards of international joint ventures with pyramidal group firms, Global Strategy Journal, 4: 310-330.

\section{Endnotes}

1 Market capitalization data comparisons derived from the World Federation of Exchanges, Annual Statistics Guide, 2017.

2 These lberian colonized countries adopted their legal traditions primarily from the French civil law influences.

3 Venezuela is tied for $5^{\text {th }}$ place with South Korea.

4 These countries include Ecuador, which was ranked the lowest of the 72 countries studied; Venezuela, ranked $3^{\text {rd }}$; Bolivia, ranked $4^{\text {th }}$; Panama, ranked $6^{\text {th }} ;$ Mexico, ranked $8^{\text {th }}$; and Uruguay, ranked $9^{\text {th }}$.

Susan E. Perkins (susanp@uic.edu) is an Associate Professor of Strategic Management at the University of Illinois at Chicago. Her research interests include global strategy, institutional reform, leadership and market regulation. She is an expert on Brazilian corporate governance. Her research appears in journals such as Administrative Science Quarterly, Global Strategy Journal, and the Harvard Business Review. Susan was a former AIB Finalist for the Richard N. Farmer Dissertation Award. 